\title{
Characterisation of porous coatings formed on titanium under AC plasma electrolytic oxidation
}

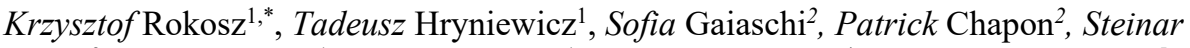 \\ Raaen $^{3}$, Eukasz Dudek ${ }^{1}$, Kornel Pietrzak ${ }^{1}$, Winfried Malorny ${ }^{4}$ and Radion Ciuperca ${ }^{5}$ \\ ${ }^{1}$ Division of BioEngineering and Surface Electrochemistry, Department of Engineering and \\ Informatics Systems, Faculty of Mechanical Engineering, Koszalin University of Technology, \\ Racławicka 15-17, PL 75-620 Koszalin, Poland \\ ${ }^{2}$ HORIBA Jobin Yvon S.A.S., Avenue de la Vauve - Passage Jobin Yvon, CS 45002 - 91120 \\ Palaiseau, France \\ ${ }^{3}$ Department of Physics, Norwegian University of Science and Technology (NTNU), Realfagbygget \\ E3-124 Høgskoleringen 5, NO 7491 Trondheim, Norway \\ ${ }^{4}$ Hochschule Wismar-University of Applied Sciences Technology, Business and Design, Faculty of \\ Engineering, DE 23966 Wismar, Germany \\ ${ }^{5}$ Manufacturing Engineering, Technical University of Moldova, str. Studenţilor, 9/8, blocul de studii \\ nr. 6, Chisinau, Republic of Moldova
}

\begin{abstract}
The Plasma Electrolytic Oxidation (PEO) process may be used to fabricate porous coatings on titanium. The ranges of voltages used in case of these plasma treatments are different. It has been found that for DC PEO processing the voltage must be higher than that in the case of $\mathrm{AC}$ PEO treatment. In addition, the shape and frequency of the voltage signal have also an influence. In the paper scanning electron microscopy (SEM) with energy dispersive X-ray spectroscopy, X-ray photoelectron spectroscopy and glow discharge optical emission spectroscopy (GDEOS) were used to characterise obtained coatings. It was found that it is possible to obtain the porous coatings enriched with phosphorus and copper by use of AC-PEO at only $200 \mathrm{Vpp}$, while increasing the PEO voltage results in non-porous and cracked coatings. Based on GDEOS for $200 \mathrm{Vpp}$ three sublayers were used, with ranges of 0-400, and 400-2400, and 2400-3600 seconds of sputtering time for first, and second, and transition sublayers respectively. XPS spectra for sample processed at $200 \mathrm{Vpp}$ indicate in top $10 \mathrm{~nm}$ layer presence of titanium as $\mathrm{Ti}^{4+}$ and phosphorous as phosphates (most likely $\mathrm{PO}_{4}^{3-}, \mathrm{HPO}_{4}{ }^{2-}, \mathrm{H}_{2} \mathrm{PO}_{4}^{-}, \mathrm{P}_{2} \mathrm{O}_{7}^{3-}$ ).
\end{abstract}

\section{Introduction}

Light metals such as titanium, niobium, tantalum, zirconium, and their alloys may be treated by Plasma Electrolytic Oxidation also known as Micro Arc Oxidation (MAO). Nowadays, for biomedical and industrial applications the titanium [9-11] and its alloys [1224] are mostly used. The main advantage of use of that electrolytical method is possibility of forming the porous micro-coatings, which may be enriched with selected materials. It

\footnotetext{
${ }^{*}$ Corresponding author: rokosz@tu.koszalin.pl
} 
should be also pointed out that in literature there are informations about nano-layers, that may be obtained by the electropolishing techniques [1-8]. The PEO coatings used as biomaterials should have hydroxyapatite-like structure enriched with bactericidal copper $[10,25-29]$, what is very important in the case of surgery of human and animal bodies. The coatings are fabricated at DC or AC voltages of several hundred volts. It addition, it should be noted that errors related to the voltage instability as well as with the distortion associated with the shape of the wave are also affected [30-31]. Porous coatings obtained by DC PEO processes with the use of concentrated phosphoric acid based electrolyte were described in previous papers [32-37].

\section{Methods}

The titanium samples $(10 \times 10 \times 2 \mathrm{~mm})$ were treated by PEO treatment in electrolyte consisting of $1 \mathrm{~L}$ of $85 \%$ phosphoric acid $\mathrm{H}_{3} \mathrm{PO}_{4}$ with $500 \mathrm{~g}$ copper nitrate trihydrate $\mathrm{Cu}\left(\mathrm{NO}_{3}\right)_{2} \cdot 3 \mathrm{H}_{2} \mathrm{O}$ for $3 \mathrm{~min}$ at voltages of $200 \mathrm{Vpp}, 250 \mathrm{Vpp}$ and $300 \mathrm{Vpp}$ (volts peak-topeak) by using $50 \mathrm{~Hz}$ alternating current transformer. The set ups of SEM, EDS, GDOES, XPS measuring systems were described earlier in $[18,20,31]$.

\section{Results and discussion}

In Figure 1, SEM micrographs of coatings formed on titanium after AC PEO treatment at voltages 200,250 , and $300 \mathrm{~V}_{\mathrm{pp}}$, are presented. The coating obtained at the voltage of $200 \mathrm{~V}_{\mathrm{pp}}$ may be characterized as porous with well-developed surface. The developed morphology type can be used for different applications (biomaterials, catalysts, as well as for air and space industry).
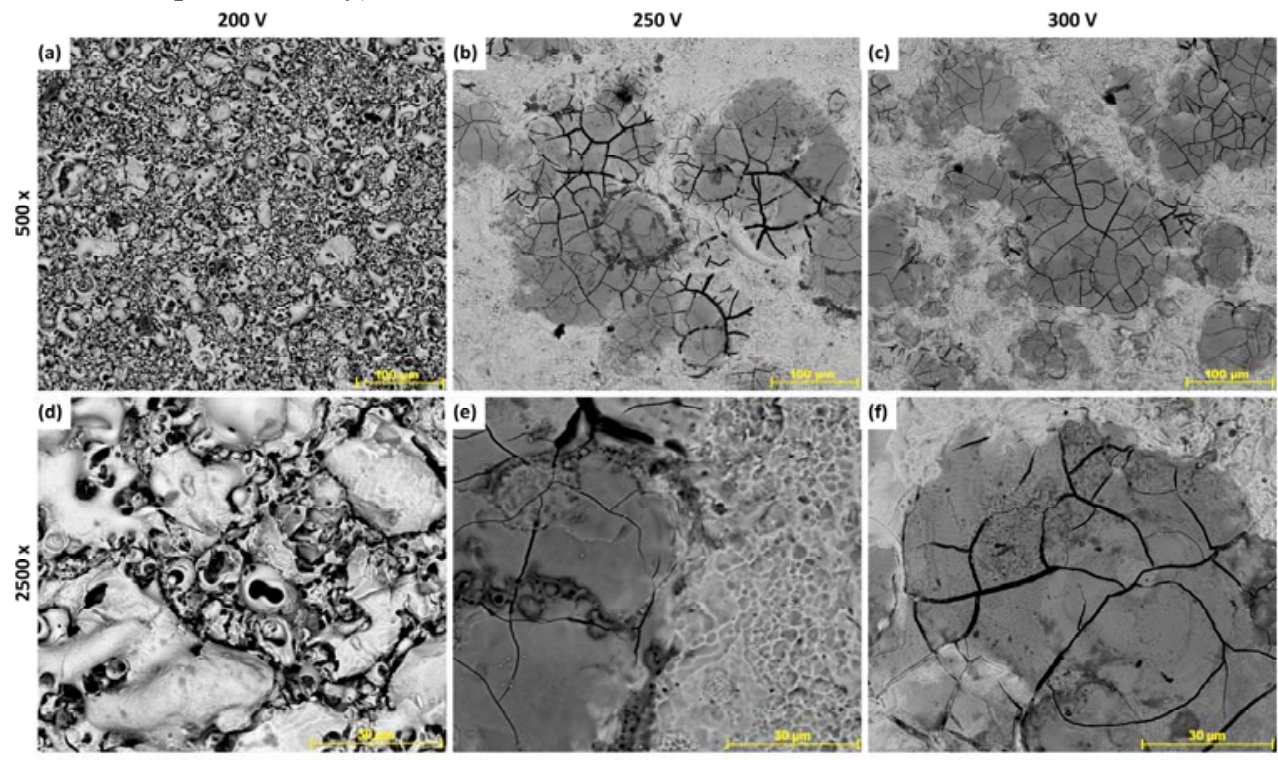

Fig. 1. SEM pictures of coatings formed on Titanium Grade 2 after AC PEO treatment at voltages of $200 \mathrm{~V}_{\mathrm{pp}}, 250 \mathrm{~V}_{\mathrm{pp}}, 300 \mathrm{~V}_{\mathrm{pp}}$. Magnifications 500 and 2500 times.

The surfaces obtained at voltages of 250 and $300 \mathrm{~V}_{\mathrm{pp}}$ look not so well developed as that one obtained at $200 \mathrm{~V}_{\mathrm{pp}}$. Higher voltage correlates with more energy delivered to create plasma on the material surface during the process. Under these conditions, the increasing voltage seems to have a negative influence on building porous, well developed surfaces. 
Based on the EDS data from 5 records for each sample generated at magnification of 500 times the $\mathrm{Cu} / \mathrm{P}$ atomic ratios were equal to $0.18 \pm 0.01$ (first quartile 0.18 ; third quartile 0.19 ), $0.15 \pm 0.04$ (first quartile 0.12; third quartile 0.19), and $0.07 \pm 0.02$ (first quartile 0.05 ; third quartile 0.09 ). The $\mathrm{Cu} / \mathrm{P}$ ratio has negative correlation with voltage of the $\mathrm{AC}$ PEO process. Based on the presented SEM and EDS results, where the porous coating was obtained at $200 \mathrm{~V}_{\mathrm{pp}}$, the authors decided to continue studies (GDOES and XPS) on that coating only. In Figure 2A, the GDEOS results of the analysis of coating obtained on CP Titanium Grade 2 after AC PEO treatment at the voltage of $200 \mathrm{~V}_{\mathrm{pp}}$, are presented. The presence of copper and phosphorus as the basic elements of coating, and titanium as a matrix was described and proved by the higher given EDS data. The obtained coating can be divided into three sub-layers, i.e. the first one with open and organic contaminated from the atmosphere pores; the second one, semi-porous with lower concentrations of phosphorus, hydrogen, oxygen and carbon, and the third transition sub-layer in which decreasing phosphorus, oxygen signals, and increasing titanium signal can be observed.
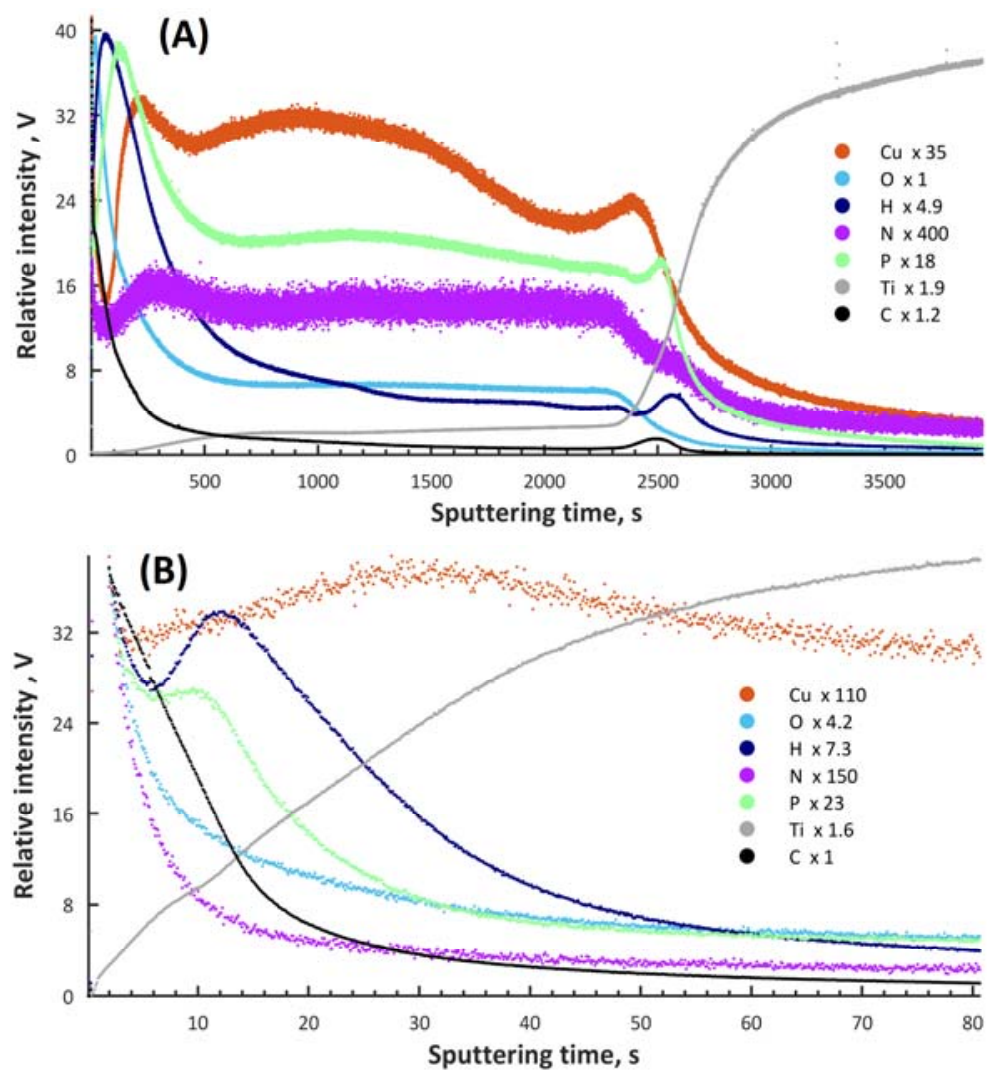

Fig. 2. GDEOS results for copper (a), phosphorus (b), oxygen (c), titanium (d), hydrogen (e), carbon (f), nitrogen (g), and summary (h) of coatings formed on Titanium Grade 2 after AC PEO treatment at voltages of $200 \mathrm{~V}_{\mathrm{pp}}(\mathrm{A})$, and $300 \mathrm{~V}_{\mathrm{pp}}(\mathrm{B})$.

The first sub-layer thickness corresponds with approximately $400 \mathrm{~s}$ of sputtering time. The second sub-layer is thicker than the first one and refers to approximately 400 up to $2400 \mathrm{~s}$ resulting in thickness corresponding with $2000 \mathrm{~s}$ of sputtering time. The third sub-layer, with the thickness corresponding with the sputtering time of $1100 \mathrm{~s}$, should be treated as the transition one. Local maxima in case of hydrogen and carbon can be considered as organic contaminations coming from the air that can prove the existence of pore-in-pore structures. 
In Figure 2B, the GDEOS results of coating obtained on CP Titanium Grade 2 after AC PEO treatment at voltage of $300 \mathrm{~V}_{\mathrm{pp}}$, are presented. Based on the GDEOS data one can conclude that the coating obtained at $300 \mathrm{~V}_{\mathrm{pp}}$ is enriched in copper, phosphorus, oxygen and titanium. The obtained results indicate that much thinner single layer is formed, referred to approximately $40 \mathrm{~s}$ of sputtering time, with the reference to coating obtained at $200 \mathrm{~V}_{\mathrm{pp}}$ (at approximately $3500 \mathrm{~s}$ of sputtering time).

In Figure 3, XPS spectra of coatings formed on CP Titanium Grade 2 after AC PEO treatment at the voltage of $200 \mathrm{~V}_{\mathrm{pp}}$, are presented. The obtained XPS results show that the top $10 \mathrm{~nm}$ layer is constituted from titanium (most likely $\mathrm{Ti}^{4+}$ ) and phosphates (most likely $\mathrm{PO}_{4}{ }^{3-}, \mathrm{HPO}_{4}{ }^{2-}, \mathrm{H}_{2} \mathrm{PO}_{4}^{-}, \mathrm{P}_{2} \mathrm{O}_{7}{ }^{3-}$ ) presence, which are confirmed by the binding energies, i.e. Ti 2 $\mathrm{p}_{3 / 2}(460.1 \mathrm{eV}), \mathrm{O} 1 \mathrm{~s}(531.9 \mathrm{eV})$, P 2p (134.4 eV).
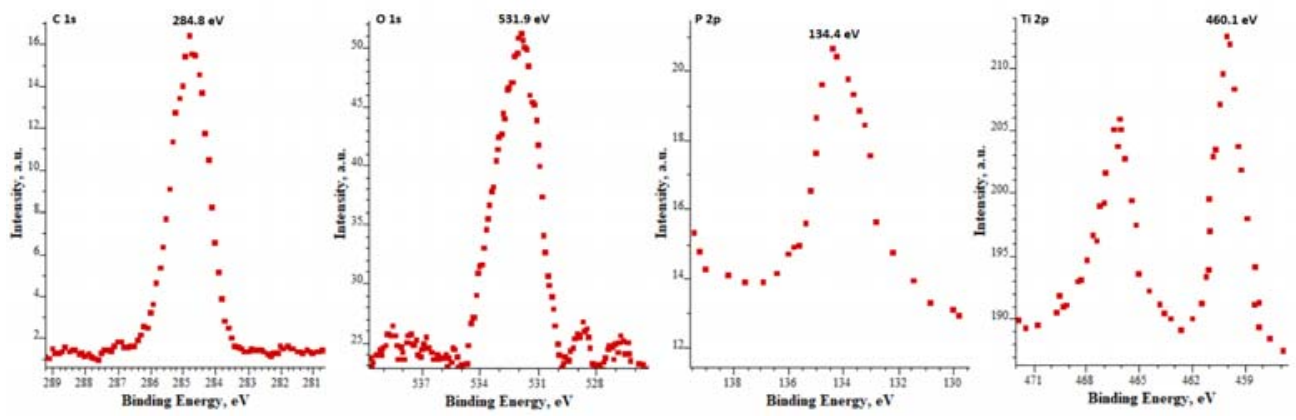

Fig. 3. XPS results for coatings formed on Titanium Grade 2 after AC PEO treatment at voltages of $200 \mathrm{~V}_{\mathrm{pp}}$.

\section{Conclusions}

- It is possible to obtain the porous coatings enriched with phosphorus and copper by use of AC-PEO at only $200 \mathrm{Vpp}$.

- The use of voltages higher than $200 \mathrm{Vpp}$ results in non-porous and cracked PEO coatings

- Three-sublayer model was proposed based on GDEOS data, where porosity was confirmed by detection of organic contamination.

- Considering GDEOS results total thickness of coatings obtained at voltage of $200 \mathrm{Vpp}$ was ca. more than 80 times thicker than the ones obtained at $300 \mathrm{Vpp}$.

- The top $10 \mathrm{~nm}$ layer is composed of titanium (most likely $\mathrm{Ti}^{4+}$ ) and phosphates (most likely $\mathrm{PO}_{4}{ }^{3-}, \mathrm{HPO}_{4}{ }^{2-}, \mathrm{H}_{2} \mathrm{PO}_{4}^{-}, \mathrm{P}_{2} \mathrm{O}_{7}{ }^{2-}$ ), which are confirmed by the binding energies, i.e. Ti $2 \mathrm{p}_{3 / 2}(460.1 \mathrm{eV}), \mathrm{O} 1 \mathrm{~s}(531.9 \mathrm{eV}), \mathrm{P} 2 \mathrm{p}(134.4 \mathrm{eV})$.

This work was supported by a subsidy from Grant OPUS 11 of National Science Centre, Poland, with registration number 2016/21/B/ST8/01952, titled "Development of models of new porous coatings obtained on titanium by Plasma Electrolytic Oxidation in electrolytes containing phosphoric acid with addition of calcium, magnesium, copper and zinc nitrates".

\section{References}

1. K. Rokosz, T. Hryniewicz, Anti-Corros. Method. M. 61, 1, 57-64 (2014)

2. M. Kušnerová, J. Valíček, M. Harničárová, T. Hryniewicz, K. Rokosz, Z. Palková, V. Václavík, M. Řepka, M. Bendová, Meas. Sci. Rev. 13, 1, 1-6 (2013) 
3. R. Rokicki, T. Hryniewicz, C. Pulletikurthi, K. Rokosz, N. Munroe, J. Mater. Eng. Perform. 24, 1634-1640 (2015)

4. K. Rokosz, T. Hryniewicz, Int. J. Mater. Res. 104, 12, 1223-1232 (2013)

5. K. Rokosz, T. Hryniewicz, S. Raaen, Teh. Vjesn. 21, 3, 533-538 (2014)

6. K. Rokosz, J. Lahtinen, T. Hryniewicz, S. Rzadkiewicz, Surf. Coat. Tech. 276, 516$520(2015)$

7. K. Rokosz, F. Simon, T. Hryniewicz, S. Rzadkiewicz, Surf. Interface Anal. 47, 1, 87$92(2015)$

8. J. Valíček, M. Držík, T. Hryniewicz, M. Harničárová, K. Rokosz, M. Kušnerová, K. Barčová, D. Bražina, Meas. Sci. Rev. 12 (2012)

9. K. Rokosz, T. Hryniewicz, P. Chapon, S. Raaen, Ricardo Zschommler Sandim, H. J. Spectrosc. 2016, 1-7 (2016)

10. K. Rokosz, T. Hryniewicz, S. Raaen, P. Chapon, Ł. Dudek, Surf. Interface Anal. 49, 4, 303-315 (2017)

11. W. Simka, A. Iwaniak, G. Nawrat, A. Maciej, J. Michalska, K. Radwański, J. Gazdowicz, Electrochim. Acta 54, 27, 6983-6988 (2009)

12. A. Kazek-Kęsik, J. Jaworska, M. Krok-Borkowicz, M. Gołda-Cępa, M. Pastusiak, M. Brzychczy-Włoch, E. Pamuła, A. Kotarba, W. Simka, Surf. Coat. Tech. 302, 158-165 (2016)

13. A. Krząkała, A. Kazek-Kęsik, W. Simka, RSC Adv. 3, 19725-19743 (2013)

14. A. Kazek-Kęsik, K. Kuna, W. Dec, M. Widziołek, G. Tylko, A. M. Osyczka, W. Simka, J. Biomed. Mater. Res B 104, 5, 903-913 (2016)

15. G. Dercz, W. Simka, A. Kazek-Kęsik, A. Maciej, S. Ogierman, Sol. St. Phen 227, 531-534 (2015)

16. A. Krzạkała, J. Młyński, G. Dercz, J. Michalska, A. Maciej, Ł. Nieuzyła, W. Simka, Archives of Metallurgy and Materials 59, 1, 199-204 (2014)

17. A. Kazek-Kęsik, K. Pietryga, M. Basiaga, A. Blacha-Grzechnik, G. Dercz, I. Kalemba-Rec, E. Pamuła, W. Simka, Surf. Coat. Tech. 328, 1-12 (2017)

18. K. Rokosz, T. Hryniewicz, S. Raaen, P. Chapon, Int. J. Adv. Manuf. Technol. 87, 912, 3497-3512 (2016)

19. K. Rokosz, T. Hryniewicz, S. Raaen, Int. J. Adv. Manuf. Technol. 85, 9-12, $2425-$ 2437 (2016)

20. K. Rokosz, T. Hryniewicz, S. Raaen, P. Chapon, F. Prima, Int. J. Adv. Manuf. Technol. 89, 2953-2965 (2017)

21. K. Rokosz, T. Hryniewicz, S. Raaen, Teh. Vjesn. 24, 1, 193-198 (2017)

22. A. Kazek-Kȩsik, G. Dercz, I. Kalemba, K. Suchanek, A.I. Kukharenko, D.M. Korotin, J. Michalska, A. Krzạkała, J. Piotrowski, E.Z. Kurmaev, S.O. Cholakh, W. Simka, Mat. Sci. Eng. C 39, 1, 259-272 (2014)

23. A. Kazek-Kęsik, D. Łastówka, A. Donesz-Sikorska, G. Dercz, W. Simka, J. Electrochem. Soc. 162, D589-D597 (2015)

24. A. Kazek-Kęsik, G. Dercz, K. Suchanek, I. Kalemba-Rec, J. Piotrowski, W. Simka, Surf. Coat. Tech. 276, 59-69 (2015)

25. K. Rokosz, T. Hryniewicz, Ł. Dudek, D. Matýsek, J. Valíček, M. Harničárová, J. Nanosci. Nanotechno. 16, 8, 7814-7817 (2016)

26. K. Rokosz, T. Hryniewicz, W. Malorny, Mater. Sci. Forum. 862, 86-95 (2016) 
27. K. Rokosz, T. Hryniewicz, D. Matýsek, S. Raaen, J. Valíček, Ł. Dudek, M. Harničárová Materials 9, 5, 318 (2016)

28. K. Rokosz, T. Hryniewicz, S. Raaen, W. Malorny, Journal of Mechanical and Energy Engineering, 1, 41, 23-30 (2017)

29. J. Kolmas, E. Groszyk, D. Kwiatkowska-Rózycka, Substituted hydroxyapatites with antibacterial properties. Biomed. Res. Int. 2014 (2014)

30. K. Zajkowski, Neural Computing and Applications 24, 2, 431-439 (2014)

31. S. Duer, K. Zajkowski, I. Płocha, R. Duer, Neural. Comput. Appl. 22, 7, 1581-1590 (2013)

32. K. Rokosz, T. Hryniewicz, K. Pietrzak, P. Sadlak, J. Valíček, Adv. Mater. Sci. 17, 4, 55-67 (2017)

33. K. Rokosz, T. Hryniewicz, S. Gaiaschi, P. Chapon, S. Raaen, K. Pietrzak, W. Malorny, J. Salvador Fernandes, Metals 8, 112 (2018)

34. K. Rokosz, T. Hryniewicz, S. Gaiaschi, P. Chapon, S. Raaen, K. Pietrzak, Malorny, W. Metals 7, 354 (2017),

35. K. Rokosz, T. Hryniewicz, K. Pietrzak, W. Malorny, Adv. Mater. Sci. 17, 2, 41-54 (2017)

36. K. Rokosz, T. Hryniewicz, L. Dudek, W. Malorny, Adv. Mater. Sci 15, 3, 41-47 (2015)

37. K. Rokosz, T. Hryniewicz, L. Dudek, A. Schutz, J. Heeg, M. Winecke, Adv. Mater. Sci 16, 3, 15-25 (2016) 